\title{
The Premasseteric Branch of the Facial Artery: A Review and Translation of Adachi's Work
}

\author{
Stephen J. Bordes ${ }^{1}$, Sina Zarrintan ${ }^{2}$, Joe Iwanaga ${ }^{3}$, Marios Loukas ${ }^{1}$, R. Shane Tubbs ${ }^{3}$ \\ 1. Anatomy, St. George's University, St. George's, GRD 2. Cardiac/Thoracic/Vascular Surgery, Tabriz University of \\ Medical Sciences, Tabriz, IRN 3. Neurosurgery, Tulane Center for Clinical Neurosciences, Tulane University School of \\ Medicine, New Orleans, USA
}

Corresponding author: Joe Iwanaga, iwanagajoeca@gmail.com

\begin{abstract}
The premasseteric branch of the facial artery is a variable posterior branch that is closely associated with the anterior border of the masseter muscle. Since its first description, the premasseteric branch has been described using different terms such as the masseteric or posterior branch of the facial artery. While the artery's anatomy is known, it is infrequently discussed in the literature. This manuscript reviews the artery's origin, course, and importance during maxillofacial procedures, especially those involving manipulation of the masseter. We also provide a translation of Adachi's 1928 German text describing the branch.
\end{abstract}

Categories: Plastic Surgery, Anatomy

Keywords: premasseteric branch, facial artery, anatomist, anatomy, maxillofacial surgery

\section{Introduction And Background}

Buntaro Adachi (1865-1945) was a Japanese physician, anatomist, and anthropologist well-known for his research and depictions of anatomical variation in man [1,2]. Adachi was born and raised in Honshu, Japan; he attended Tokyo Imperial University and later taught at the University of Okayama Medical School [1]. Adachi's studies in human anatomy then brought him to Strasbourg, Germany from 1899-1904, after which he returned to Japan as a professor at Kyoto Imperial University [1]. Following mandatory retirement from the university in 1925, Adachi became the president of Osaka Medical College [1]. His two most famous works, Das Arteriensystem der Japaner (1928) and the two-part Das Venensystem der Japaner (1933 and 1940), originally written in German, are still widely recognized and highly regarded in human vascular and variation research [1-5]. In his 1928 publication, Adachi extensively described a variation of the facial artery, which he named the "ramus premassetericus," also known as the premasseteric or posterior branch of the facial artery [5]. Anatomical knowledge of the artery is important during craniofacial procedures involving the masseter muscle; however, modern texts have yet to standardize its terminology, which has led to some ambiguity in the literature regarding its origin, course, and variation [6]. Herein, we provide a translation of Adachi's description of the "ramus premassetericus" as well as a review of the literature regarding this

Received 09/03/2020

Review began 09/09/2020 Review ended 09/14/2020 Published 09/18/2020

๑) Copyright 2020 Bordes et al. This is an open access article distributed under the terms of the Creative Commons Attribution License CC-BY 4.0., which permits unrestricted use, distribution, and reproduction in any medium, provided the original author and source are credited. arterial branch to summarize existing knowledge so that we can apply it toward better and safer surgery.

\section{Review}

\section{Translation of Adachi's "ramus premassetericus" of the maxillary artery}

The maxillary artery and the anterior facial vein are close to each other at the jaw edge, whereas, in the face, they rise divergently so that the former runs in front of the latter (the maxillary artery is accompanied by particularly fine double veins, as previously mentioned by Bardelebens and Sobotta). From there, when the artery and vein separate from each other, in the majority of faces, the vein accompanies a fine arterial branch emerging acute-angled from the maxillary artery on the edge of the mandible. The branch, which is called the "ramus premassetericus," thus turns at the front edge of the masseter muscle upward, but ends very soon or anastomoses with the surrounding arteries.

The ramus premassetericus rarely forms a considerable artery (Figure 1), and almost only when the continuation of the maxillary artery, which runs in front of the ramus, is weak. 


\section{Cureus}

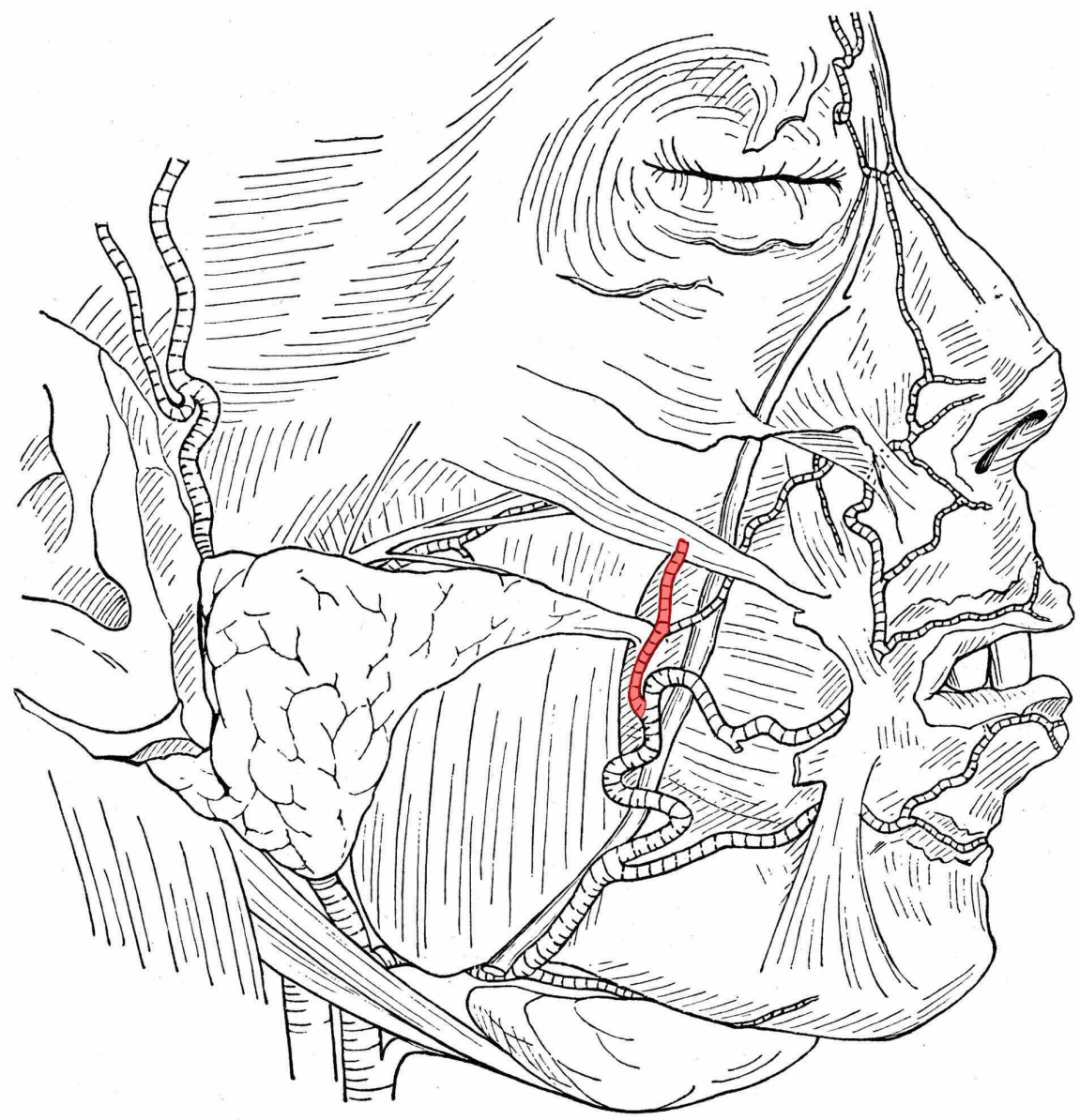

FIGURE 1: A strongly developed ramus premassetericus that accompanies the anterior facial vein in a 23-year-old male

Adapted from Adachi B's Anatomie der Japaner 1: Das Arteriensystem der Japaner. Kyoto; 1928, with modification [5]

Among 132 halves of the face (66 cadavers: 52 male, 14 female; 1907 and 1908), the said ramus premassetericus was four times (male: two times right; female: two times left) very strong, about as strong as the usual continuation of the maxillary artery running in front of the ramus or even stronger. So in this case, in the face, the maxillary artery, which accompanies the anterior facial vein, turns into this ramus while the actual continuation of the maxillary artery is a branch of the ramus premassetericus or is simply missing.

In Figure 2, we present a somewhat special case (the case was encountered by chance in 1918) where the ramus premassetericus is strongly developed in the lower half of the face and the actual maxillary artery is missing. 


\section{Cureus}

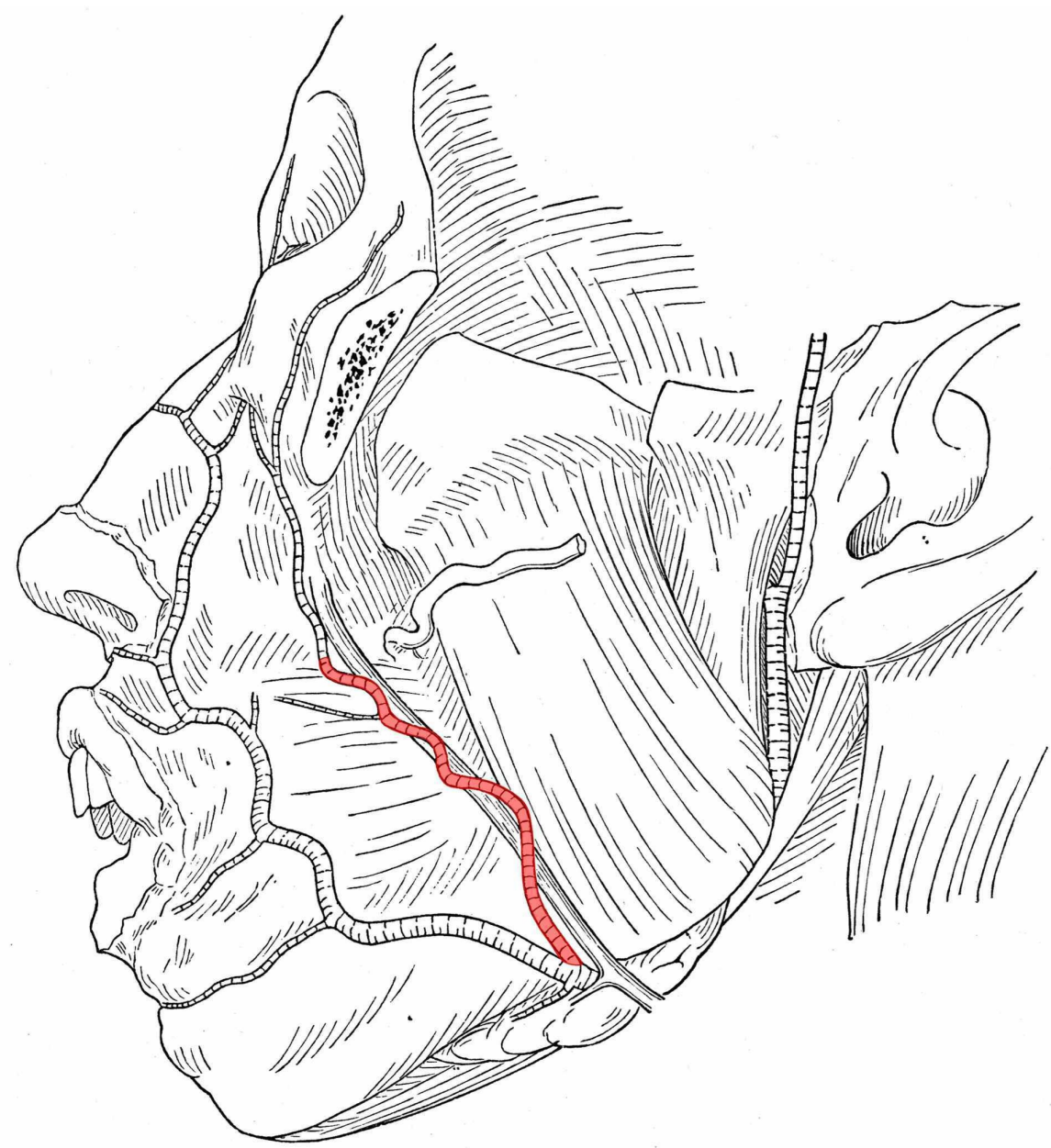

FIGURE 2: The ramus premassetericus is strongly developed in the lower half of the face and the actual maxillary artery is missing in a 19year-old male

Adapted from Adachi B's Anatomie der Japaner 1: Das Arteriensystem der Japaner. Kyoto; 1928, with modification [5]

The latter is present, however, in the upper half of the face and yet stronger than the continuation of the ramus premassetericus.

Even with stronger development, the ramus premassetericus offers no striking image when the anterior facial vein is disregarded. At the preparations where the vein already has been removed or displaced from its natural position, it is often doubtful whether it is an ordinary maxillary artery or a very developed ramus premassetericus. Such preparations are not included in the aforementioned 132 halves of the face.

In several textbooks (Cunningham, Murrich in Piersol, Poirier, Testut), the ramus is mentioned as the “masseteric branch,” "branches massétérines,” or “massétérine inferieure.” By name, the description of Murrich is applicable. Various pictures of the ramus are also found in the atlases of Broesike (Vol. II, figs. 350-354) and Toldt (Gefäßlehre, figs. 968, 969, and 1046). Broesike called the branch "A. premasseterica." In a specimen of veins of Toldt (fig. 1046), the anterior facial vein accompanies a strong arterial branch.

\section{Literature review}

Branches of the Facial Artery

The facial artery provides the blood supply for a significant portion of the face. The artery originates from the external carotid artery (ECA) and gives off cervical (ascending palatine artery, tonsillar branch, submental artery, and glandular branches) and facial branches (superior and inferior labial branches, lateral nasal branch, and angular artery) anteriorly [6-10]. Variations exist in which the facial artery produces posterior branches, but these branches often remain unnamed [8]. 


\section{Cureus}

The premasseteric, also known as masseteric or posterior, branch of the facial artery is a better known posterior branch that was named as early 1928 by Adachi; however, it has seldom been discussed in the literature (Figure 3) [5].

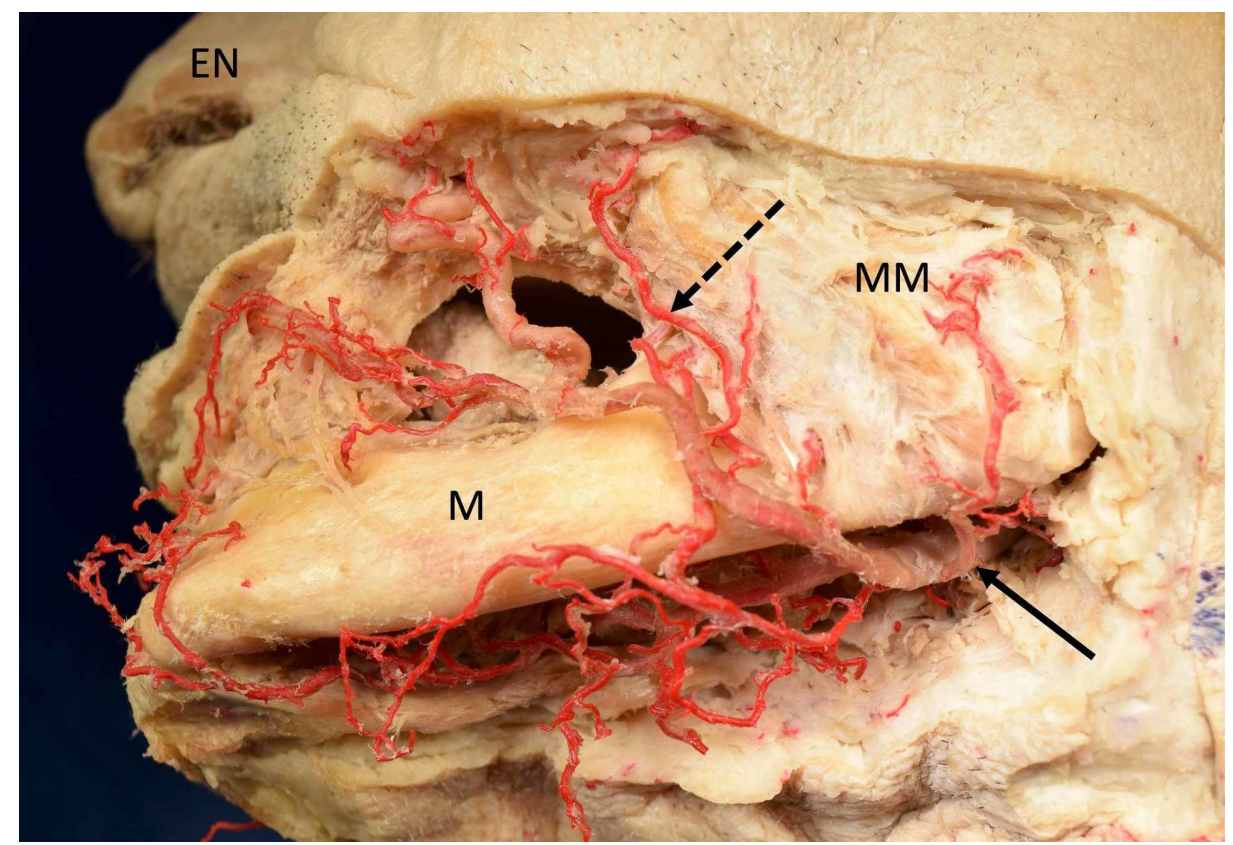

\section{FIGURE 3: Left premasseteric branch (dotted arrow) of the facial artery (solid arrow) in a Caucasian cadaveric specimen}

EN: external nose; M: mandible; MM: masseter muscle

The premasseteric branch of the facial artery originates in the submandibular region and crosses the ramus of the mandible and travels near the facial vein along the anterior border of the masseter to supply surrounding tissues $[5,6,8,11-13]$. It is found to divide into superficial and deep branches that usually pierce the masseter and terminate in the region of the parotid duct $[6,8,12]$. The artery has been seen to anastomose with the superior masseteric branch of the transverse facial artery as well as the middle and inferior masseteric branches of the maxillary, facial, or ECAs $[5,6,11]$. The arterial branch is generally small, but variations do exist in which the vessel is as large as the facial artery itself [5,6]. According to Mağden et al. (2009), the mean diameter of the premasseteric branch at its origin was $1.12 \mathrm{~mm}$ (range: 0.60-2.10 mm) [6].

Blood Supply of the Masseter Muscle and Surgical Considerations

The artery has been implicated as a potential source of complication in craniofacial procedures specifically involving the masseter muscle, which is supplied by masseteric branches of the facial, transverse facial, and maxillary arteries $[6,7,14]$. Regarding the blood supply of the masseter, Hwang et al. (2001) proposed using the terms superficial and deep middle masseteric arteries originating from either the ECA or common carotid artery [15]. A study by Ariji et al. (2001), using Doppler sonography, investigated the detection rate of the arteries that supply the masseter and revealed that the masseter branch of the facial artery was detected on $100 \%$ of sides (72 sides) [14]. According to Won et al. (2012), the masseteric branch of the facial artery and masseteric branch of the premasseteric artery were observed in $88 \%(22 / 25)$ and $56 \%(14 / 25)$ of specimens, respectively [16].

Typically, this premasseteric branch exists as a single vessel; however, reports have noted the facial artery giving rise to multiple premasseteric branches [7,11]. As a result, knowledge of potential variation is crucial in order to reduce the risk of transection during maxillofacial and plastic surgery procedures such as musculo-mucosal flaps, treatment of facial palsy, benign masseteric hypertrophy, parotid tumor resection, and lower lip repair, to name a few $[6,8,11,17,18]$. Even for general dentists and oral surgeons, the premasseteric branch might cause bleeding as the facial artery in this area travels near the buccal periosteum in the lower molar region and can be injured during oral surgery [19].

\section{Terminology}


This literature review has revealed that there are several different terms for the premasseteric branch of the facial artery. Moreover, some articles have used similar terms for different structures and vice versa (Table

1). Therefore, this needs to be amended for future studies and for the readers' better understanding.

\begin{tabular}{|c|c|c|}
\hline Artery & Terminology used & Author \\
\hline \multirow{8}{*}{ Premasseteric branch of the facial artery } & Ramus premassetericus & Adachi (1928) [3] \\
\hline & \multirow{2}{*}{ Premasseteric branch of the facial artery } & $\begin{array}{l}\text { Mağden et al. } \\
\text { (2009) [6] }\end{array}$ \\
\hline & & Nayak (2019) [7] \\
\hline & $\begin{array}{l}\text { Posterior (premasseteric) branch of the } \\
\text { facial artery }\end{array}$ & $\begin{array}{l}\text { Padur et al. (2019) } \\
\text { [8] }\end{array}$ \\
\hline & Masseteric branch of the facial artery & $\begin{array}{l}\text { Arjii et al. (2001) } \\
\text { [14] }\end{array}$ \\
\hline & Masseteric artery & $\begin{array}{l}\text { Marinho et al. } \\
\text { (1991) [11] }\end{array}$ \\
\hline & \multirow{2}{*}{ Premasseteric artery } & $\begin{array}{l}\text { Vasudha et al. } \\
\text { (2018) [12] }\end{array}$ \\
\hline & & $\begin{array}{l}\text { Won et al. (2012) } \\
{[16]}\end{array}$ \\
\hline $\begin{array}{l}\text { Posterior branch of the premasseteric artery that supplies the } \\
\text { masseter }\end{array}$ & $\begin{array}{l}\text { Masseteric branch of the premasseteric } \\
\text { artery }\end{array}$ & $\begin{array}{l}\text { Won et al. (2012) } \\
{[16]}\end{array}$ \\
\hline $\begin{array}{l}\text { Posterior branch of the facial artery inferior to the origin of the } \\
\text { premasseteric branch }\end{array}$ & Masseteric branch of the facial artery & $\begin{array}{l}\text { Won et al. (2012) } \\
{[16]}\end{array}$ \\
\hline Masseteric branch of the maxillary artery & Masseteric artery & $\begin{array}{l}\text { Hwang et al. (2001) } \\
{[17]}\end{array}$ \\
\hline
\end{tabular}

TABLE 1: Overlapping terminology concerning blood supply to the masseter

\section{Conclusions}

Since its detailed description in 1928 , the premasseteric branch of the facial artery has been a source of little discussion. Knowledge of the artery and its variations is crucial during maxillofacial procedures in order to avoid complications. While the artery is often small, a large branch or multiple branches can result in significant hemorrhage if the anatomy of the masseter muscle and its surrounding structures is not fully appreciated. This literature review has raised some new questions, i.e., regarding clinical consequences and terminology, to be addressed. Further studies to identify this branch are definitely needed.

\section{Additional Information}

\section{Disclosures}

Conflicts of interest: In compliance with the ICMJE uniform disclosure form, all authors declare the following: Payment/services info: All authors have declared that no financial support was received from any organization for the submitted work. Financial relationships: All authors have declared that they have no financial relationships at present or within the previous three years with any organizations that might have an interest in the submitted work. Other relationships: All authors have declared that there are no other relationships or activities that could appear to have influenced the submitted work.

\section{Acknowledgements}

The authors would like to thank those who donated their bodies for the advancement of medical education and research.

\section{References}

1. Watanabe K, Shoja MM, Loukas M, Tubbs RS: Buntaro Adachi (1865-1945): Japanese master of human anatomic variation. Clin Anat. 2012, 25:957-960. 10.1002/ca.22182

2. Tubbs RS, Loukas M, Kato D, Ardalan MR, Shoja MM, Gadol AA: The evolution of the study of anatomy in 
Japan. Clin Anat. 2009, 22:425-435. 10.1002/ca.20781

3. Adachi B: Das Venensystem der Japaner. Kyoto University Press, Kyoto, Japan; 1933.

4. Adachi B: Das Venensystem der Japaner. Adachi B (ed): Kyoto University Press, Kyoto, Japan; 1940.

5. Adachi B: Das Arteriensystem der Japaner. Adachi B (ed): Kyoto University Press, Kyoto, Japan; 1928.

6. Mağden O, Göçmen-Mas N, Senan S, Edizer M, Karaçayli U, Karabekir HS: The premasseteric branch of facial artery: its importance for craniofacial surgery. Turk Neurosurg. 2009, 19:45-50.

7. Nayak SB: Triple premasseteric branches of facial artery. J Craniofac Surg. 2019, 30:e168-e169. 10.1097/SCS.0000000000005102

8. Padur AA, Kumar N: Unusual branching pattern and termination of facial artery and its clinical implications for facial operations. J Vasc Bras. 2019, 18:e20190021. 10.1590/1677-5449.190021

9. Loukas M, Hullett J, Louis RG Jr, Kapos T, Knight J, Nagy R, Marycz D: A detailed observation of variations of the facial artery, with emphasis on the superior labial artery. Surg Radiol Anat. 2006, 28:316-324. 10.1007/s00276-006-0093-0

10. Lasjaunias P, Berenstein A, Doyon D: Normal functional anatomy of the facial artery . Radiology. 1979, 133:631-638. 10.1148/133.3.631

11. Marinho LH, Shanahan DA, Langdon JD, Sinnatamby CS: The inferiorly based masseter muscle flap: anatomical basis for its use in head and neck reconstructive surgery. Int J Oral Maxillofac Surg. 1991, 20:100-105. 10.1016/s0901-5027(05)80718-0

12. Vasudha T, D’Sa D, Gowda S: A study on course and variations of facial artery on the face . Int J Anat Res. 2018, 6:4928-4932. 10.16965/ijar.2017.510

13. Gray's Anatomy: The Anatomical Basis of Clinical Practice. Standring S (ed): Elsevier, London, UK; 2016.

14. Ariji Y, Kimura Y, Gotoh M, Sakuma S, Zhao YP, Ariji E: Blood flow in and around the masseter muscle: normal and pathologic features demonstrated by color Doppler sonography. Oral Surg Oral Med Oral Pathol Oral Radiol Endod. 2001, 91:472-482. 10.1067/moe.2001.111760

15. Hwang K, Kim YJ, Chung IH, Lee SI: Deep middle masseteric artery (dMMA) attributed to hemorrhage in resection of masseter muscle and mandibular angle. J Craniofac Surg. 2001, 12:381-385. 10.1097/00001665200107000-00013

16. Won SY, Choi DY, Kwak HH, Kim ST, Kim HJ, Hu KS: Topography of the arteries supplying the masseter muscle: using dissection and Sihler's method. Clin Anat. 2012, 25:308-313. 10.1002/ca.21205

17. Hwang K, Kim YJ, Park H, Chung IH: Selective neurectomy of the masseteric nerve in masseter hypertrophy . J Craniofac Surg. 2004, 15:780-784. 10.1097/00001665-200409000-00016

18. Conley J, Gullane PJ: The masseter muscle flap . Laryngoscope. 1978, 88:605-612. 10.1002/lary.1978.88.4.605

19. Iwanaga J, Shiromoto K, Tubbs RS: Releasing incisions of the buccal periosteum adjacent to the lower molar teeth can injure the facial artery: an anatomical study. Surg Radiol Anat. 2020, 42:31-34. 10.1007/s00276019-02319-3 